\title{
The Impact of Baseline Serum Creatinine on Complete Remission Rate and Long-Term Outcome in Patients with Severe Lupus Nephritis
}

\author{
Stephen M. Korbet William L. Whittier Edmund J. Lewis \\ for the Collaborative Study Group \\ Section of Nephrology, Department of Medicine, Rush University Medical Center, \\ Chicago, Ill., USA
}

\author{
Key Words \\ Lupus nephritis · Remission · Serum creatinine $\cdot$ Proteinuria
}

\begin{abstract}
Background/Aim: We assess the impact of serum creatinine at baseline on complete remission rate and long-term outcome in severe lupus nephritis (SLN). Methods: A total of 86 adult patients with SLN [International Society of Nephrology/Renal Pathology Society (ISN/RPS) class IV lesions] were evaluated based on baseline serum creatinine levels $(\leq 1.0,1.01-1.5,1.51-2.0$, 2.01-3.0, and $>3.0 \mathrm{mg} / \mathrm{dl} ; \mathrm{n}=22,23,16,12$, and 13 , respectively). The complete remission rates (serum creatinine level of $\leq 1.4 \mathrm{mg} / \mathrm{dl}$ and proteinuria of $\leq 0.33 \mathrm{~g} /$ day) and long-term outcomes (stable renal function, dialysis, and death) were compared. The patients were followed for 121 \pm 64 months. Results: The baseline clinical features were similar, but the chronicity index was significantly higher with increasing levels of serum creatinine. Complete remission rates were significantly higher in patients with lower levels of serum creatinine ( 86 vs. 52 vs. 19 vs. 25 vs. $0 \%, p<0.0001)$. Patients with a baseline serum creatinine level of $\leq 1.0 \mathrm{mg} / \mathrm{dl}$ were $>16$ times as likely (OR 16.2; 95\% CI: 4.2-61.5) to attain a complete remission and $>6$ times as likely (OR $6.1 ; 95 \%$ CI: 1.9-18.6) to have stable renal function at the last follow-up as compared to patients with a serum creatinine level of $>1.0 \mathrm{mg} / \mathrm{dl}$. The 15-year renal survival rate was greatest among those patients with a baseline serum creatinine level of $\leq 1.0 \mathrm{mg} / \mathrm{dl}$ ( 76 vs. $57 \mathrm{vs} .48$ vs. 25 vs. $10 \%, p<0.0001)$. Conclusion: The prognosis of SLN is significantly affected by the serum creatinine level at baseline. The complete remission rate is highest, and the long-term prognosis most favorable, in patients with a baseline serum creatinine level of $\leq 1.0 \mathrm{mg} / \mathrm{dl}$. This emphasizes the importance of early diagnosis and treatment.




\section{Introduction}

In severe lupus nephritis (SLN), attainment of a complete remission with treatment is associated with a significantly improved prognosis and long-term outcome [1-10]. It has been shown that the level of serum creatinine is predictive of response to therapy and longterm outcome, with poorer complete remission rates and outcomes in those patients presenting with elevated serum creatinine levels [3, 5, 9-16]. As a result, early diagnosis and treatment of SLN while renal function is better preserved is critical in order to ensure improved response rates and long-term prognosis [17].

The purpose of this study was to determine the impact of the level of serum creatinine at baseline on the complete remission rate and long-term prognosis of patients with SLN.

\section{Subjects and Methods}

\section{Patients}

This retrospective study is based on 86 adult patients who originally participated in a prospective, controlled trial of plasmapheresis in SLN [18]. In this study, with an extended follow-up ( $121 \pm 64$ months overall) the patient data (standard therapy and plasmapheresis patients) were pooled because there had been no significant differences between the two treatment groups during the previous therapeutic trial [18]. The purpose of the current study was to determine the impact of the serum creatinine level at baseline on complete remission rate and long-term prognosis. Patients were categorized by baseline serum creatinine level and divided into the following categories: a serum creatinine of $\leq 1.0 \mathrm{mg} / \mathrm{dl}(\mathrm{n}=22), 1.01-1.5$ $\mathrm{mg} / \mathrm{dl}(\mathrm{n}=23), 1.51-2.0 \mathrm{mg} / \mathrm{dl}(\mathrm{n}=16), 2.01-3.0 \mathrm{mg} / \mathrm{dl}(\mathrm{n}=12)$, and $>3.0 \mathrm{mg} / \mathrm{dl}(\mathrm{n}=13)$.

The entry criteria, therapeutic and medical management protocols, and results of the initial study have been previously described $[18,19]$. In brief, patients were eligible when they were $\geq 16$ years of age, had systemic lupus erythematosus as defined by the American Rheumatism Association [20], and had biopsy-proven SLN. Patients who had a serum creatinine level of $>6 \mathrm{mg} / \mathrm{dl}$, had previous plasmapheresis, or were pregnant were excluded from the study.

Entry criteria required a histologic diagnosis of SLN using a modification of the 1982 World Health Organization (WHO) classification of lupus nephritis [21-23]. An adequate biopsy contained $>10$ nonsclerotic glomeruli, and the diagnosis of SLN was based on the presence of proliferation and/or necrosis in $\geq 50 \%$ of the glomeruli with or without concomitant membranous glomerulonephritis [18]. This pathologic rubric comprises three morphologically discrete forms of lupus glomerulonephritis: (1) segmental glomerulonephritis with active and/or necrotizing lesions in $\geq 50 \%$ of the glomeruli (category III $\geq 50 \% ; 24$ patients), (2) diffuse glomerulonephritis (category IV; 35 patients), and (3) membranous glomerulonephritis with superimposed severe segmental ( $\geq 50 \%$ glomerular involvement, category Vc $\geq 50 \%$; 20 patients) or diffuse proliferative glomerulonephritis (category Vd; 6 patients). Because we have previously shown that the prognosis of these lesions is defined by the distribution of their proliferative component (segmental vs. global inflammation) irrespective of the presence of membranous glomerulonephritis, we have grouped them accordingly into category III $\geq 50 \% \pm V$ ( 44 patients) and category IV $\pm V$ ( 41 patients) [24]. Based on the International Society of Nephrology/Renal Pathology Society (ISN/RPS) classification [25, 26], all patients had class IV-S or G \pm V. One patient with SLN was not classifiable.

Clinical, biochemical, and serological information on the patients was obtained at baseline and at specified follow-up times during the study (weekly for 8 weeks, then at weeks 12, 18, and 24 , and every 8 weeks thereafter for 2-5 years). The level of proteinuria was determined 
Table 1. Baseline clinical characteristics

\begin{tabular}{|c|c|c|c|c|c|c|}
\hline & \multicolumn{5}{|c|}{ Baseline serum creatinine } & \multirow[t]{2}{*}{$\mathrm{p}$} \\
\hline & $\begin{array}{l}<1.0 \\
\mathrm{mg} / \mathrm{dl}\end{array}$ & $\begin{array}{l}1.01-1.5 \\
\mathrm{mg} / \mathrm{dl}\end{array}$ & $\begin{array}{l}1.51-2.0 \\
\mathrm{mg} / \mathrm{dl}\end{array}$ & $\begin{array}{l}2.01-3.0 \\
\mathrm{mg} / \mathrm{dl}\end{array}$ & $\begin{array}{l}>3.0 \\
\mathrm{mg} / \mathrm{dl}\end{array}$ & \\
\hline Patients & $22(25 \%)$ & $23(27 \%)$ & $16(19 \%)$ & $12(14 \%)$ & $13(15 \%)$ & \\
\hline Age, years & $28 \pm 8$ & $32 \pm 13$ & $35 \pm 14$ & $31 \pm 13$ & $34 \pm 14$ & 0.48 \\
\hline Female & 19 (86\%) & $20(87 \%)$ & $12(75 \%)$ & $9(75 \%)$ & $12(92 \%)$ & 0.63 \\
\hline \multicolumn{7}{|l|}{ Race } \\
\hline White & 13 (59\%) & 15 (65\%) & $12(75 \%)$ & 7 (58\%) & $7(54 \%)$ & 0.78 \\
\hline Black/other & 9 & 8 & 4 & 5 & 6 & \\
\hline Serum $\mathrm{Cr}, \mathrm{mg} / \mathrm{dl}$ & $0.8 \pm 0.1$ & $1.3 \pm 0.2$ & $1.8 \pm 0.1$ & $2.5 \pm 0.4$ & $4.0 \pm 1.2$ & \\
\hline Proteinuria, g/day & $5.2 \pm 3.3$ & $5.5 \pm 4.5$ & $8.1 \pm 4.9$ & $6.6 \pm 3.3$ & $4.7 \pm 2.3$ & 0.14 \\
\hline \multicolumn{7}{|l|}{ Treatment } \\
\hline Standard & 11 & 14 & 7 & 7 & 7 & 0.85 \\
\hline Plasmapheresis & 11 & 9 & 9 & 5 & 6 & \\
\hline
\end{tabular}

based on 24-hour urine collections. Information from the last follow-up on the clinical status of the patients with respect to mortality, end-stage renal disease (ESRD), and biochemical results for serum creatinine and urine protein levels was collected.

\section{Treatment Protocol}

The details of the treatment protocols for this study have been published previously [18, 19]. All patients initially received standard therapy with prednisone at $60 \mathrm{mg} /$ day orally and cyclophosphamide at $2 \mathrm{mg} / \mathrm{kg} /$ day orally. Forty patients were randomly assigned to receive standard therapy plus plasmapheresis 3 times weekly for 4 weeks in addition to this treatment. After the initial 4 weeks of treatment, patients who improved clinically received cyclophosphamide at $1 \mathrm{mg} / \mathrm{kg} /$ day for an additional month, after which it was discontinued. The dosage of prednisone was gradually tapered over a 22-week period to $20 \mathrm{mg}$ on alternate days. Patients whose renal symptoms had worsened by 4 weeks were continued on the initial highdose prednisone and cyclophosphamide for an additional 4 weeks, and patients in the plasmapheresis arm of the study also received an additional 12 treatments [19].

\section{Outcome Variables}

The outcomes were defined as follows: (1) complete remission: serum creatinine of $\leq 1.4$ $\mathrm{mg} / \mathrm{dl}$ and proteinuria of $\leq 0.33 \mathrm{~g} /$ day within 5 years of entering the study; (2) ESRD: a serum creatinine level of $\geq 6 \mathrm{mg} / \mathrm{dl}$ or the initiation of renal replacement therapy, and (3) death.

\section{Statistical Analyses}

The comparison of the clinical, laboratory, and pathologic characteristics using the $\chi^{2}$ test for categorical data and the Kruskal-Wallis test (nonparametric ANOVA) for continuous data was performed using GraphPad InStat version 3.06 for Windows (GraphPad Software, San Diego, Calif., USA; www.graphpad.com). For the analysis of length of time from entry to ESRD (renal survival) and patient survival without ESRD, product-limit life-table distributions were compared with the log-rank test statistic using GraphPad Prism version 5.00 for Windows. The results are reported as means $\pm S D$, and $p<0.05$ was considered significant. 
Korbet et al.: The Impact of Baseline Serum Creatinine on Complete Remission Rate and Long-Term Outcome in Patients with Severe Lupus Nephritis

Table 2. Histologic features

\begin{tabular}{|c|c|c|c|c|c|c|}
\hline & \multicolumn{5}{|c|}{ Baseline serum creatinine } & \multirow[t]{2}{*}{$\mathrm{p}$} \\
\hline & $\begin{array}{l}<1.0 \\
\mathrm{mg} / \mathrm{dl}\end{array}$ & $\begin{array}{l}1.01-1.5 \\
\mathrm{mg} / \mathrm{dl}\end{array}$ & $\begin{array}{l}1.51-2.0 \\
\mathrm{mg} / \mathrm{dl}\end{array}$ & $\begin{array}{l}2.01-3.0 \\
\mathrm{mg} / \mathrm{dl}\end{array}$ & $\begin{array}{l}>3.0 \\
\mathrm{mg} / \mathrm{dl}\end{array}$ & \\
\hline Patients & 22 & 23 & 16 & 12 & 13 & \\
\hline WHO class III $\geq 50 \% \pm V$ & $13(59 \%)$ & $8(35 \%)$ & $10(63 \%)$ & $5(42 \%)$ & $8(62 \%)$ & 0.30 \\
\hline WHO class IV $\pm \mathrm{V}$ & 9 & 14 & 6 & 7 & 5 & \\
\hline Unclassified & - & 1 & - & - & - & \\
\hline Activity index & $11 \pm 3$ & $11 \pm 6$ & $13 \pm 3$ & $14 \pm 4$ & $14 \pm 6$ & 0.06 \\
\hline Activity index $\geq 12$ & $9(41 \%)$ & $7(30 \%)$ & $8(50 \%)$ & $9(75 \%)$ & $9(69 \%)$ & 0.06 \\
\hline Chronicity index & $2 \pm 2$ & $3 \pm 2$ & $3 \pm 3$ & $5 \pm 2$ & $5 \pm 2$ & 0.002 \\
\hline Chronicity index $\geq 4$ & $5(23 \%)$ & $11(48 \%)$ & $6(38 \%)$ & $9(75 \%)$ & $10(77 \%)$ & 0.007 \\
\hline
\end{tabular}

Table 3. Follow-up

\begin{tabular}{|c|c|c|c|c|c|c|}
\hline & \multicolumn{5}{|c|}{ Baseline serum creatinine } & \multirow[t]{2}{*}{$\mathrm{p}$} \\
\hline & $\begin{array}{l}<1.0 \\
\mathrm{mg} / \mathrm{dl}\end{array}$ & $\begin{array}{l}1.01-1.5 \\
\mathrm{mg} / \mathrm{dl}\end{array}$ & $\begin{array}{l}1.51-2.0 \\
\mathrm{mg} / \mathrm{dl}\end{array}$ & $\begin{array}{l}2.01-3.0 \\
\mathrm{mg} / \mathrm{dl}\end{array}$ & $\begin{array}{l}>3.0 \\
\mathrm{mg} / \mathrm{dl}\end{array}$ & \\
\hline Patients & 22 & 23 & 16 & 12 & 13 & \\
\hline Follow-up, months & $133 \pm 60$ & $122 \pm 64$ & $130 \pm 67$ & $130 \pm 59$ & $71 \pm 60$ & 0.04 \\
\hline CR & $19(86 \%)$ & $12(52 \%)$ & $3(19 \%)$ & $3(25 \%)$ & $0(0 \%)$ & $<0.0001$ \\
\hline \multicolumn{7}{|l|}{ Time to CR, months } \\
\hline Median & 6.3 & 12.3 & 23.3 & 18.3 & - & 0.33 \\
\hline Range & $1.3-56.5$ & $2.3-20.3$ & $8.3-54.0$ & $7.5-37.5$ & - & \\
\hline \multicolumn{7}{|l|}{ Status at last follow-up } \\
\hline ESRD & $2(9 \%)$ & $3(13 \%)$ & $6(38 \%)$ & $7(58 \%)$ & $4(31 \%)$ & 0.01 \\
\hline ESRD/death & $3(14 \%)$ & $4(17 \%)$ & $1(6 \%)$ & $1(8 \%)$ & $6(46 \%)$ & 0.04 \\
\hline Death & $0(0 \%)$ & $4(17 \%)$ & $3(19 \%)$ & $0(0 \%)$ & $2(15 \%)$ & 0.16 \\
\hline Stable renal function & $17(77 \%)$ & $12(52 \%)$ & $6(38 \%)$ & $4(33 \%)$ & $1(8 \%)$ & 0.001 \\
\hline
\end{tabular}

\section{Results}

\section{Baseline Clinical Characteristics}

The clinical characteristics for the 86 patients categorized by the level of serum creatinine at baseline ( $\leq 1.0$ vs. $1.01-1.5$ vs. $1.51-2.0$ vs. $2.01-3.0$ vs. $>3.0 \mathrm{mg} / \mathrm{dl}$ ) are shown in table 1. There were no differences between the groups in age, gender, race, or level of proteinuria at baseline. As expected, there was a significant difference in serum creatinine levels. There was no difference in the proportion of patients receiving plasmapheresis in addition to standard therapy between the groups.

\section{Histologic Features}

The proportion of patients with WHO class III $\geq 50 \% \pm$ V lesions was similar between the groups (table 2). There was also no significant difference in the activity index, or the proportion of patients with an activity index $\geq 12$, between the groups. There was, however, a significant difference between the groups in the chronicity index and the proportion of patients with a 
Korbet et al.: The Impact of Baseline Serum Creatinine on Complete Remission Rate and Long-Term Outcome in Patients with Severe Lupus Nephritis

Table 4. Cumulative complete remission rates

\begin{tabular}{|c|c|c|c|c|c|c|}
\hline & \multicolumn{5}{|c|}{ Baseline serum creatinine } & \multirow[t]{2}{*}{$\mathrm{p}$} \\
\hline & $\begin{array}{l}<1.0 \\
\mathrm{mg} / \mathrm{dl}\end{array}$ & $\begin{array}{l}1.01-1.5 \\
\mathrm{mg} / \mathrm{dl}\end{array}$ & $\begin{array}{l}1.51-2.0 \\
\mathrm{mg} / \mathrm{dl}\end{array}$ & $\begin{array}{l}2.01-3.0 \\
\mathrm{mg} / \mathrm{dl}\end{array}$ & $\begin{array}{l}>3.0 \\
\mathrm{mg} / \mathrm{dl}\end{array}$ & \\
\hline Patients & 22 & 23 & 16 & 12 & 13 & \\
\hline $\begin{array}{l}\text { Cumulative complete remission rates } \\
6 \text { months } \\
12 \text { months } \\
18 \text { months } \\
24 \text { months } \\
36 \text { months } \\
48 \text { months }\end{array}$ & $\begin{array}{l}41 \% \\
50 \% \\
63 \% \\
68 \% \\
81 \% \\
87 \%\end{array}$ & $\begin{array}{l}14 \% \\
29 \% \\
53 \% \\
65 \% \\
65 \% \\
65 \%\end{array}$ & $\begin{array}{r}0 \% \\
8 \% \\
8 \% \\
18 \% \\
18 \% \\
18 \%\end{array}$ & $\begin{array}{r}0 \% \\
9 \% \\
9 \% \\
20 \% \\
20 \% \\
34 \%\end{array}$ & $0 \%$ & 0.0002 \\
\hline
\end{tabular}

Fig. 1. Cumulative complete remission rate (censoring for dialysis and death) among patients with SLN based on the serum creatinine level at baseline $(\mathrm{p}=$ 0.0002).

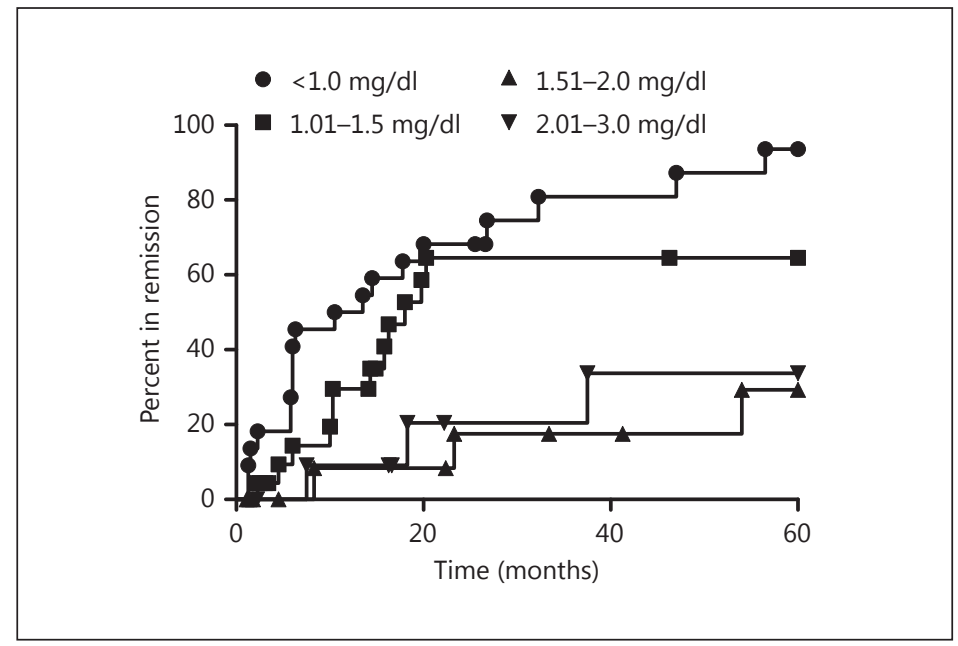

chronicity index $\geq 4$. The chronicity index ( $2 \pm 2$ vs. $3 \pm 2$ vs. $3 \pm 3$ vs. $5 \pm 2$ vs. $5 \pm 2, p=0.002$ ) and the proportion of patients with a chronicity index $\geq 4$ ( 23 vs. 48 vs. 38 vs. 75 vs. $77 \%, p=$ $0.007)$ were lowest among the patients with the lowest level of serum creatinine $(\leq 1.0 \mathrm{mg} /$ $\mathrm{dl}$ ), increased with progressively higher levels of serum creatinine, and highest in patients with a serum creatinine level of $>3.0 \mathrm{mg} / \mathrm{dl}$.

\section{Follow-Up}

The proportion of patients attaining a complete remission was significantly greater among those with the lowest level of serum creatinine at baseline (tables 3, 4; fig. 1) and decreased with increasing serum creatinine levels ( 86 vs. 52 vs. 19 vs. 25 vs. $0 \%, p<0.0001$ ). Patients with a baseline serum creatinine level of $\leq 1.0 \mathrm{mg} / \mathrm{dl}$ were $>16$ times as likely (OR 16.2; 95\% CI: 4.2-61.5; $\mathrm{p}<0.0001$ ) to attain a complete remission as patients with a serum creatinine level of $>1.0 \mathrm{mg} / \mathrm{dl}$. While the time to complete remission was shortest in those patients with the lowest level of serum creatinine, this was not significant ( $6.3 \mathrm{vs} .12 .3 \mathrm{vs}$. 23.3 vs. 18.3 months, $\mathrm{p}=0.33$ ). By life-table analysis (table 4 ; fig. 1 ), the cumulative complete remission rate at 5 years was significantly greater for patients with the lowest level of serum creatinine ( 94 vs. 65 vs. 29 vs. 34 vs. $0 \%, p=0.0002$ ). 
Korbet et al.: The Impact of Baseline Serum Creatinine on Complete Remission Rate and Long-Term Outcome in Patients with Severe Lupus Nephritis

Table 5. Renal survival and patient survival without ESRD

\begin{tabular}{|c|c|c|c|c|c|c|}
\hline & \multicolumn{5}{|c|}{ Baseline serum creatinine } & \multirow{2}{*}{$\mathrm{p}$} \\
\hline & $\begin{array}{l}\leq 1.0 \\
\mathrm{mg} / \mathrm{dl}\end{array}$ & $\begin{array}{l}1.01-1.5 \\
\mathrm{mg} / \mathrm{dl}\end{array}$ & $\begin{array}{l}1.51-2.0 \\
\mathrm{mg} / \mathrm{dl}\end{array}$ & $\begin{array}{l}2.01-3.0 \\
\mathrm{mg} / \mathrm{dl}\end{array}$ & $\begin{array}{l}>3.0 \\
\mathrm{mg} / \mathrm{dl}\end{array}$ & \\
\hline Patients & 22 & 23 & 16 & 12 & 13 & \\
\hline Renal survival & & & & & & $<0.0001$ \\
\hline 1 year & $100 \%$ & $91 \%$ & $86 \%$ & $92 \%$ & $51 \%$ & \\
\hline 5 years & $81 \%$ & $82 \%$ & $72 \%$ & $67 \%$ & $10 \%$ & \\
\hline 10 years & $81 \%$ & $82 \%$ & $48 \%$ & $38 \%$ & $10 \%$ & \\
\hline 15 years & $76 \%$ & $57 \%$ & $48 \%$ & $25 \%$ & $10 \%$ & \\
\hline Patient survival without ESRD & & & & & & $<0.0001$ \\
\hline 1 year & $100 \%$ & $87 \%$ & $75 \%$ & $92 \%$ & $38 \%$ & \\
\hline 5 years & $81 \%$ & $69 \%$ & $63 \%$ & $67 \%$ & $8 \%$ & \\
\hline 10 years & $81 \%$ & $69 \%$ & $42 \%$ & $38 \%$ & $8 \%$ & \\
\hline 15 years & $76 \%$ & $40 \%$ & $42 \%$ & $25 \%$ & $8 \%$ & \\
\hline
\end{tabular}

At the last follow-up (table 3), a significantly greater proportion of patients with the lowest level of serum creatinine had stable renal function ( 77 vs. 52 vs. 38 vs. 33 vs. $8 \%, p=$ 0.001 ) and fewer progressed to ESRD ( 23 vs. 30 vs. 44 vs. 66 vs. $77 \%, p=0.007$ ) compared to those with higher levels of serum creatinine. Patients with a baseline serum creatinine level of $\leq 1.0 \mathrm{mg} / \mathrm{dl}$ were $>6$ times as likely (OR 6.1; 95\% CI: 1.9-18.6; $\mathrm{p}=0.001$ ) to be alive with stable renal function at the last follow-up as patients with a serum creatinine level of $>1.0 \mathrm{mg} / \mathrm{dl}$. The overall renal survival (table 5; fig. 2) and patient survival without ESRD (table 5; fig. 3) were significantly greater in patients with the lowest level of serum creatinine at baseline $(\leq 1.0 \mathrm{mg} / \mathrm{dl})$. The 15-year renal survival rate based on the level of serum creatinine at baseline was 76 versus 57 versus 48 versus 25 versus $10 \%(\mathrm{p}<0.0001)$. The 15 -year patient survival rate without ESRD based on the level of serum creatinine at baseline was 76 versus 40 versus 42 versus 25 versus $8 \%(p<0.0001)$.

\section{Discussion}

We find that in patients with SLN, the serum creatinine level at baseline is highly predictive of outcome, with the best prognosis being seen in those patients with a baseline serum creatinine level of $\leq 1.0 \mathrm{mg} / \mathrm{dl}$ in whom the chronicity index on renal biopsy was lowest, suggesting less irreversible damage. The complete remission rates and long-term renal survival as well as patient survival without ESRD were significantly higher in patients with a baseline serum creatinine level of $\leq 1.0 \mathrm{mg} / \mathrm{dl}$ than in those with a level of $>1.0 \mathrm{mg} / \mathrm{dl}$. Patients with a baseline serum creatinine level of $\leq 1.0 \mathrm{mg} / \mathrm{dl}$ were $>16$ times as likely to attain a complete remission, and did so in a shorter period of time, as compared to patients with a serum creatinine level of $>1.0 \mathrm{mg} / \mathrm{dl}$. Additionally, the long-term renal survival and patient survival without ESRD were significantly greater in patients with a serum creatinine level of $\leq 1.0 \mathrm{mg} / \mathrm{dl}$. Patients with a baseline serum creatinine level of $\leq 1.0 \mathrm{mg} / \mathrm{dl}$ were $>6$ times as likely to be alive with stable renal function at the last follow-up as patients with a serum creatinine level of $>1.0 \mathrm{mg} /$ dl. Thus, patients with SLN with a serum creatinine level of $\leq 1.0 \mathrm{mg} / \mathrm{dl}$ at baseline have an extremely favorable prognosis.

The level of serum creatinine at baseline significantly impacts the complete remission rate with immunosuppressive treatment and the long-term prognosis of patients with SLN 


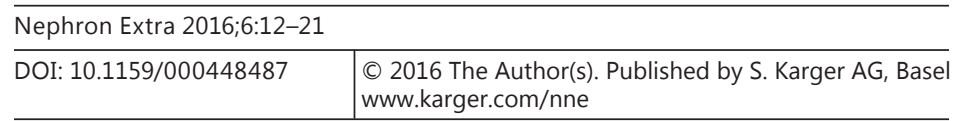

Korbet et al.: The Impact of Baseline Serum Creatinine on Complete Remission Rate and Long-Term Outcome in Patients with Severe Lupus Nephritis

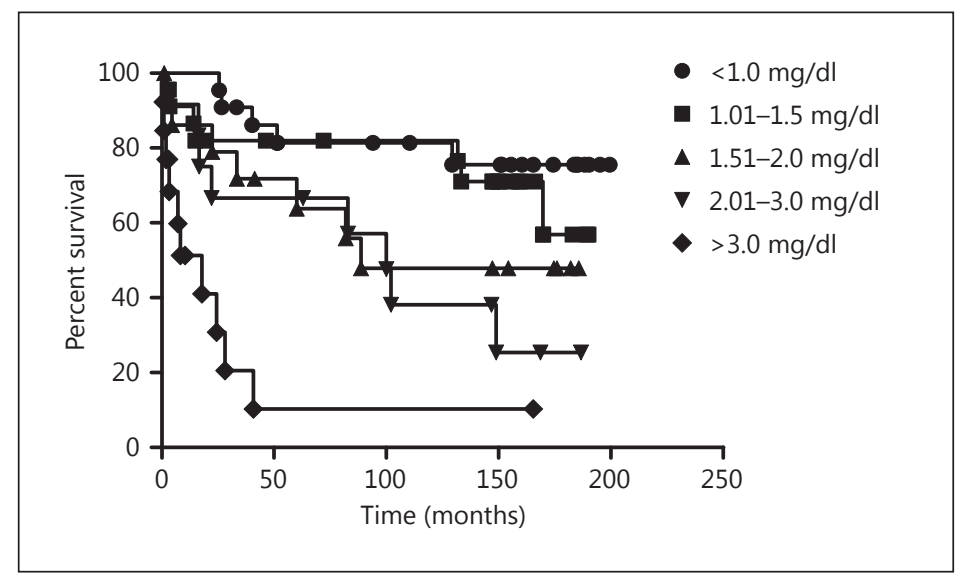
for death) among patients with SLN based on the serum creatinine level at baseline $(\mathrm{p}<0.0001)$.

Fig. 3. Patient survival without ESRD among patients with SLN based on the serum creatinine level $(\mathrm{p}<0.0001)$.

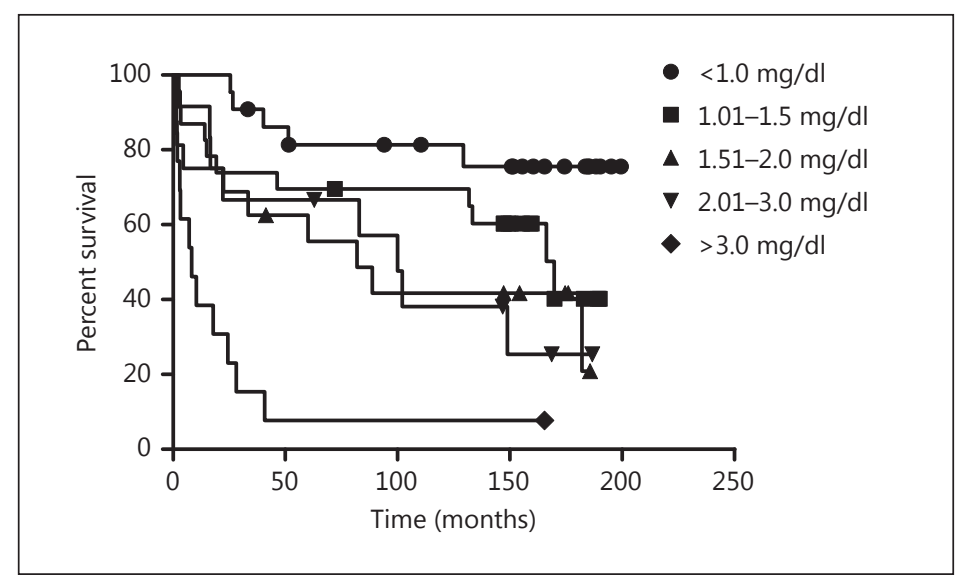

$[3,5]$. We had previously shown that the cumulative remission rate over 5 years was $78 \%$ among patients with a serum creatinine level of $\leq 1.4 \mathrm{mg} / \mathrm{dl}, 48 \%$ among those patients with a serum creatinine level of $1.41-2.5 \mathrm{mg} / \mathrm{dl}$, and only $8 \%$ among patients with a serum creatinine level of $>2.5 \mathrm{mg} / \mathrm{dl}$ [5]. In the present study, we found that the cumulative complete remission rate is yet significantly higher among patients with a baseline serum creatinine level of $\leq 1.0 \mathrm{mg} / \mathrm{dl}$ (at 94\%), compared to those with a serum creatinine level of 1.01-1.5 mg/ $\mathrm{dl}$ (at 65\%) and those with a serum creatinine level of $>1.5 \mathrm{mg} / \mathrm{dl}$, where it is even lower, with no patient with a serum creatinine level of $>3.0 \mathrm{mg} / \mathrm{dl}$ attaining remission. In fact, only $12 \%$ of the patients with a baseline serum creatinine level of $>2.0 \mathrm{mg} / \mathrm{dl}$ attained complete remission. Few studies have assessed the impact of baseline serum creatinine levels on complete remission rates in SLN. Recently, Walsh et al. [16] evaluated the outcome in the $8.6 \%$ of patients in the ALMS trial with an estimated glomerular filtration rate of $<30 \mathrm{ml} /$ $\mathrm{min} / 1.73 \mathrm{~m}^{2}$ (corresponding to a serum creatinine level of approx. $\geq 2.0 \mathrm{mg} / \mathrm{dl}$ ) and found a complete remission rate of only $6 \%$. This extremely low remission rate among patients with markedly reduced renal function is consistent with that found in the current study. Thus, the higher the serum creatinine level at baseline, the lower the likelihood of attaining complete remission with treatment in SLN.

Consistent with the low remission rate observed in patients with a higher serum creatinine level is the finding of a poor overall long-term prognosis with an increased incidence of ESRD and death. In patients with lupus nephritis with a serum creatinine level of $>1.2 \mathrm{mg} / \mathrm{dl}$, the relative risk of progressive renal insufficiency or ESRD is 5.6-7 times higher than in 
Korbet et al.: The Impact of Baseline Serum Creatinine on Complete Remission Rate and Long-Term Outcome in Patients with Severe Lupus Nephritis

patients with a serum creatinine level of $<1.2 \mathrm{mg} / \mathrm{dl}[3,5,11,13]$. Austin et al. [11] found that patients with a baseline serum creatinine level of $\geq 1.4 \mathrm{mg} / \mathrm{dl}$ were $>3.5$ times more likely to progress to end-stage renal failure over 8 years of follow-up than patients having a serum creatinine level of $<1.4 \mathrm{mg} / \mathrm{dl}$ ( $23 \mathrm{vs} .6 .5 / 6.6 \%, \mathrm{p}=0.03$ ). While the results in these studies are consistent with our observations, we found that the best prognosis was for patients with a baseline serum creatinine level of $\leq 1.0 \mathrm{mg} / \mathrm{dl}$. We also observed that those patients with the best preserved renal function at baseline (serum creatinine level $\leq 1.0 \mathrm{mg} / \mathrm{dl}$ ) had significantly less evidence of chronic disease on their renal biopsy as determined by the chronicity index.

In lupus nephritis, the degree of chronic disease found on biopsy, as determined by the chronicity index, is predictive of outcome. It should not be a surprise that patients with a lower chronicity index have a greater likelihood of complete remission and a better long-term prognosis with less progression to ESRD or death compared to those patients with a high chronicity index [5-9, 11, 13]. Cortés-Hernández et al. [7] found that patients entering complete remission had a significantly lower chronicity index than those not attaining complete remission (1.8 \pm 2.6 vs. $4.1 \pm 3.4, p=0.03$ ). Mahmoud et al. [13] demonstrated that patients with lupus nephritis having a favorable outcome had a chronicity index of 1.0 as compared to 3.3 in patients with an adverse outcome (defined by doubling of serum creatinine, ESRD, and/or death). It has been shown that patients with a chronicity index of $<4$ are $>5$ times as likely to have a complete remission as patients with a chronicity index of $>4$ [5]. Additionally, the risk for progression to ESRD is $>3$ times higher in patients with a chronicity index of $>4$ [11].

A limitation of our study is that the follow-up information after the original study had been completed was retrospectively obtained. Additionally, after the formal study had ended, treatment of the patients was determined by the individual nephrologist and thus could vary significantly. As a result, it is unclear what kind of effect various forms of treatment may have had on outcomes.

In conclusion, we found that in SLN a serum creatinine level of $\leq 1.0 \mathrm{mg} / \mathrm{dl}$ at baseline is associated with the lowest amount of chronic disease on biopsy and is predictive of outcome with the greatest potential for complete remission and a favorable long-term prognosis. In those patients with a serum creatinine level of $>3.0 \mathrm{mg} / \mathrm{dl}$ in whom biopsy demonstrates significant chronic disease, the prognosis is extremely poor despite aggressive therapy. This emphasizes the importance of early diagnosis and initiation of treatment while renal function is best preserved.

\section{Appendix}

The Lupus Nephritis Collaborative Study Group included the following: Rush-Presbyterian-St. Luke's Medical Center, Chicago, Ill. - E.J. Lewis, J.L. Roberts (deceased), M.M. Schwartz, R.A. Rodby, and H.L. Corwin; George Washington University, Washington, D.C. - J.M. Lachin, S.-P. Lan, and P. Cleary; William Beaumont Hospital, Royal Oak, Mich. - J. Bernstein (deceased), H. Shapiro, and B.F. Rosenberg; Cleveland Clinic, Cleveland, Ohio - M.A. Pohl, J. Clough, and G. Gephardt; University of Colorado, Denver, Colo. - T. Berl; Henry Ford Hospital, Detroit, Mich. - N. Levin; University of Iowa, Iowa City, Iowa - L.G. Hunsicker and S. Bonsib; Evanston Hospital, Evanston, Ill. - N. Simon and H. Friederici; Northwestern University, Chicago, Ill. - F. del Greco and F.A. Carone (deceased); Ohio State University, Columbus, Ohio - L. Hebert and H.M. Sharma; University of Pennsylvania, Philadelphia, Pa. - E. Nielson and J. Tomazewski; Tufts - New England Medical Center, Boston, Mass. - A. Levey and A. Ucci; Medical College of Wisconsin, Milwaukee, Wis. - J. Lemann (deceased), S.S. Blumenthal, and 
Korbet et al:: The Impact of Baseline Serum Creatinine on Complete Remission Rate and Long-Term Outcome in Patients with Severe Lupus Nephritis

J. Garancis; New York Medical College, Valhalla, N.Y. - K. Shapiro and P. Chander; West Virginia University, Morgantown, W. Va. - F. Whittier, J.W. Graves, J. Bathon, and R. Riley.

Pathology Committee: M.M. Schwartz (Chairman), Rush-Presbyterian-St. Luke's Medical Center, Chicago, Ill.; J. Bernstein (deceased), William Beaumont Hospital, Royal Oak, Mich.; G.H. Hill (deceased), Francis Scott Key Medical Institution, a Johns Hopkins Medical Institution, Baltimore, Md.; K. Holley, Mayo Clinic, Rochester, Minn.

\section{Statement of Ethics}

The study was approved by the Institutional Review Board.

\section{Disclosure Statement}

The authors have no conflict of interest. This research received no specific grant from any funding agency in the public, commercial, or not-for-profit sectors.

\section{References}

1 Appel GB, Cohen DJ, Pirani CL, Meltzer JI, Estes D: Long-term follow-up of patients with lupus nephritis. Am J Med 1987;83:877-885.

2 Fraenkel L, MacKenzie T, Joseph L, Kashgarian M, Hayslett JP, Esdaile JM: Response to treatment as a predictor of longterm outcome in patients with lupus nephritis. J Rheumatol 1994;21:2052-2057.

-3 Levey AS, Lan SP, Corwin HL, Kasinath BS, Lachin J, Neilson EG, Hunsicker LG, Lewis EJ; Lupus Nephritis Collaborative Study Group: Progression and remission of renal disease in the Lupus Nephritis Collaborative Study. Results of treatment with prednisone and short-term oral cyclophosphamide. Ann Intern Med 1992;116: 114-123.

4 Chen YE, Korbet SM, Katz RS, Schwartz MM, Lewis EJ: Value of a complete or partial remission in severe lupus nephritis. Clin J Am Soc Nephrol 2008;3:46-53.

-5 Korbet SM, Lewis EJ, Schwartz MM, Reichlin M, Evans J, Rohde RD; Lupus Nephritis Collaborative Study Group: Factors predictive of outcome in severe lupus nephritis. Am J Kidney Dis 2000;35:904-914.

6 Chan TM, Tse KC, Tang CS, Lai KN, Li FK: Long-term outcome of patients with diffuse proliferative lupus nephritis treated with prednisolone and oral cyclophosphamide followed by azathioprine. Lupus 2005;14: 265-272.

-7 Cortés-Hernández J, Ordi-Ros J, Labrador M, Segarra A, Tovar JL, Balada E, Vilardell-Tarres M: Predictors of poor renal outcome in patients with lupus nephritis treated with combined pulses of cyclophosphamide and methylprednisolone. Lupus 2003;12:287-296.

8 Mok CC, Ying KY, Ng WL, Lee KW, To CH, Lau CS, Wong RW, Au TC: Long-term outcome of diffuse proliferative lupus glomerulonephritis treated with cyclophosphamide. Am J Med 2006;119:355.e25-e33.

-9 Moroni G, Quaglini S, Gallelli B, Banfi G, Messa P, Ponticelli C: Progressive improvement of patient and renal survival and reduction of morbidity over time in patients with lupus nephritis (LN) followed for 20 years. Lupus 2013;22:810-818.

10 Ayodele OE, Okpechi IG, Swanepoel CR: Predictors of poor renal outcome in patients with biopsy-proven lupus nephritis. Nephrology 2010;15:482-490.

11 Austin HA 3rd, Muenz LR, Joyce KM, Antonovych TA, Kullick ME, Klippel JH, Decker JL, Balow JE: Prognostic factors in lupus nephritis. Contribution of renal histologic data. Am J Med 1983;75:382-391.

12 Austin HA 3rd, Boumpas DT, Vaughan EM, Balow JE: Predicting renal outcomes in severe lupus nephritis: contributions of clinical and histologic data. Kidney Int 1994;45:544-550.

13 Mahmoud GA, Zayed HS, Ghoniem SA: Renal outcomes among Egyptian lupus nephritis patients: a retrospective analysis of 135 cases from a single centre. Lupus 2015;24:331-338.

14 Rathi M, Gupta KL, Joshi K, Gupta PK, Sharma A, Kohli HS, Jha V, Sakhuja V: Histopathological indicators of disease outcome in class IV lupus nephritis: a revisit of various indices. Rheumatol Int 2015;35:1511-1517.

15 Houssiau FA, Vasconcelos C, D’Cruz D, Sebastiani GD, de Ramon Garrido E, Danieli MG, Abramovicz D, Blockmans D, Mathieu A, Direskeneli H, Galeazzi M, Gül A, Levy Y, Petera P, Popovic R, Petrovic R, Sinico RA, Cattaneo R, Font J, Depresseux G, Cosyns JP, Cervera R: Early response to immunosuppressive therapy predicts good renal outcome in lupus nephritis: lessons from long-term followup of patients in the Euro-Lupus Nephritis Trial. Arthritis Rheum 2004;50:3934-3940. 
Korbet et al.: The Impact of Baseline Serum Creatinine on Complete Remission Rate and Long-Term Outcome in Patients with Severe Lupus Nephritis

16 Walsh M, Solomons N, Lisk L, Jayne DR: Mycophenolate mofetil or intravenous cyclophosphamide for lupus nephritis with poor kidney function: a subgroup analysis of the Aspreva Lupus Management Study. Am J Kidney Dis 2013;61:710-715.

$\checkmark 17$ Ioannidis JP, Boki KA, Katsorida ME, Drosos AA, Skopouli FN, Boletis JN, Moutsopoulos HM: Remission, relapse, and re-remission of proliferative lupus nephritis treated with cyclophosphamide. Kidney Int 2000;57:258264.

18 Lewis EJ, Hunsicker LG, Lan SP, Rohde RD, Lachin JM; Lupus Nephritis Collaborative Study Group: A controlled trial of plasmapheresis therapy in severe lupus nephritis. N Engl J Med 1992;326:1373-1379.

19 Clough JD, Lewis EJ, Lachin JM; Lupus Nephritis Collaborative Study Group: Treatment protocols of the lupus nephritis collaborative study of plasmapheresis in severe lupus nephritis; in Rock G (ed): Progress in Clinical and Biological Research. Apheresis: Proceedings of the Second International Congress of the World Apheresis Association. New York, Wiley-Liss, 1990, vol 337, pp 301-307.

20 Tan EM, Cohen AS, Fries JF, Masi AT, McShane DJ, Rothfield NF, Schaller JG, Talal N, Winchester RJ: The 1982 revised criteria for the classification of systemic lupus erythematosus. Arthritis Rheum 1982;25:1271-1277.

21 Churg J, Bernstein J, Glassock RJ: Renal Disease: Classification and Atlas of Glomerular Disease, ed 2. Tokyo/ New York, Igaku-Shoin, 1995.

22 Schwartz MM, Lan SP, Bonsib SM, Gephardt GN, Sharma HM; Lupus Nephritis Collaborative Study Group: Clinical outcome of three discrete histologic patterns of injury in severe lupus glomerulonephritis. Am J Kidney Dis 1989;13:273-283.

23 Schwartz MM, Bernstein J, Hill GS, Holley KE, Phillips EA; Lupus Nephritis Collaborative Study Group: Predictive value of renal pathology in diffuse proliferative lupus glomerulonephritis. Kidney Int 1989;36:891-896.

-24 Najafi CC, Korbet SM, Lewis EJ, Schwartz MM, Reichlin M, Evans J: Significance of histologic patterns of glomerular injury upon long-term prognosis in severe lupus glomerulonephritis. Kidney Int 2001;59:21562163.

-25 Weening JJ, D’Agati VD, Schwartz MM, Seshan SV, Alpers CE, Appel GB, Balow JE, Bruijn JA, Cook T, Ferrario F, Fogo AB, Ginzler EM, Hebert L, Hill G, Hill P, Jennette JC, Kong NC, Lesavre P, Lockshin M, Looi LM, Makino H, Moura LA, Nagata M: The classification of glomerulonephritis in systemic lupus erythematosus revisited. J Am Soc Nephrol 2004;15:241-250.

-26 Weening JJ, D’Agati VD, Schwartz MM, Seshan SV, Alpers CE, Appel GB, Balow JE, Bruijn JA, Cook T, Ferrario F, Fogo AB, Ginzler EM, Hebert L, Hill G, Hill P, Jennette JC, Kong NC, Lesavre P, Lockshin M, Looi LM, Makino H, Moura LA, Nagata M: The classification of glomerulonephritis in systemic lupus erythematosus revisited. Kidney Int 2004;65:521-530. 